\title{
An Investigation on Effectiveness of Employee Training In Hospitality Management with Special Reference to Hotel Industries in MP
}

\author{
Shoalb Ahmad Ansari \\ Department of Industrial Engg.\& Management \\ Takshshila Institute of Engineering \& Technology Jabalpur (M.P.) \\ Prof. Alok Agrawal ${ }^{2}$ \\ Department of Mechanical Engineering \\ Takshshila Institute of Engineering \& Technology Jabalpur (M.P.)
}

\begin{abstract}
Human resources are the most valuable assets of any Organization and their growth and development are essential parameters for the improvement of people and creating a favorable working environment. Training is the most important function that directly contributes to Human Resource Development of the Organizations. Hence organizing periodic training programs for Employees and Managers becomes essential. This research has examined the relationship between Training Effectiveness and Employee Performance in Hotel Industry of Madhya Pradesh. The main focus of this research work is to understand how the Hotel Industry looks upon Training as a tool for developing the potential set for their Employees and Managers. Corporate, today, spend a large amount of money on imparting Training to Employees and Managers. But prior to such a huge investment, they should evaluate the need for conducting training. There are chances in which firms can make mistakes if they are not assessing the training needs. In this research work the Training Effectiveness in Luxury Hotels of Madhya Pradesh has been examined. The overall aim of this study is to assess the importance of Training and their impact on overall Performance, better Pay and Promotions in Hospitality Industry. Tests are applied for the hypothesis testing is Chi-square for independence is used to analyze the data. Findings of the research suggest that The training helps the employees of Hotel Industry to work efficiently without much supervision, to make the more productive use of resources which results in minimum wastages of resources, and to deal with the critical situation like accidents with more safety and to learn the procedure to overcome with such situations as well as the precautions taken at the time of accidents.
\end{abstract}

Keywords: Human Resource Management, Hospitality Management, Hotel Industry, Training, Employee Performance, Chi-square test for independence.

\section{Introduction}

Human assets are one of the critical parts of hotel industry. HR creates first contact between the association and clients. Business of hotels is specifically influenced by the auspicious and great administrations gave by the lodging to their clients. The role of HR Manager in Hotel Industry is to direct employees so that they all perform well together, but firstly he or she must train their employees as a competent worker so that they must know how to perform their job.

\subsection{Concept of Training}

Preparing employees for the better performance is a vital role of Human Resource Department. It alludes to the learning, motivation and performance sessions conducted with end goal of serving parts of Organization so they can gain and apply for the information and 
capacities required by a specific occupation and association. Organization's Development and Worker's Development are joined with one another to increase long term benefit.

\subsection{Why Training}

* Improvement in Employee Performance

* Retaining Employee

* Motivating Employee

* Optimum utilization of resources

* Healthy working environment

* Creating effective and efficient Organization

\subsection{Methods of Training in Luxury Hotels}

* Sort by Objects of the Training

* Sort by Location of Training

* Sort by Contents of Training

* Orientation Training

* Apprentice Training

* Safety Training

* Promotional Training

* Certification Training

* Simulation Training

* On-the-job Training

* Hotel Administration Training

1.4 Benefits of Training

* Evaluating Employee's Performance

* Identify Employees for Promotion and Transfer

* Allows Employee to become more Productive

* Fosters Self- Development and Self- Confidence

* Increases Job Satisfaction

* Helps Employee to become more effective Problem Solver

* Increases Profitability

* Reduces Accidents

* Organizational Development

* Reduces Employee Turnover and Wastage

\subsection{Process of Training}

\section{ASSESSING THE TRAINING NEEOS}

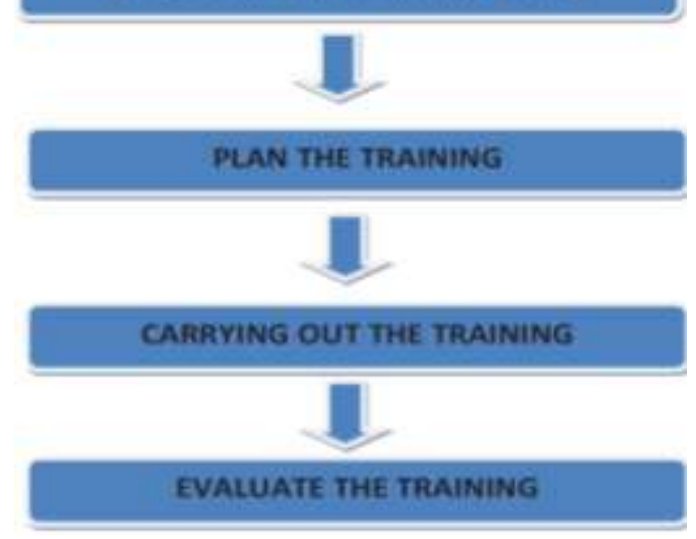




\section{Literature Review}

Wen Chang et al. (2017) empirically tested mentoring's influence on employee's promotional attitude. The results showed that mentor functions (i.e., career development and psychosocial support) were antecedents of employee promotional attitude. In addition, employee's psychological contract breach and employee's affective organizational commitment were mediators between mentor functions and promotional attitude [10].

Lillian T. Eby et al (2017) provided a comprehensive qualitative review of 67 published studies that have examined mindfulness-based training interventions conducted with employees. The findings indicate that the most common research designs were the pretest/post-test only design and the randomized waitlist control group design [3].

Islam El-Bayoumi Salem et al. (2017) scrutinize the extent of implementing cross-training in 5-star chain hotels, identified the relevant factors that should be considered to maximize the cross-training benefits and investigate its effect on hotels' organizational performance. Results revealed that it is very essential for hotel staff to be cross-trained in different departments or within the various functions within the department. An effective cross training technique can result in better job performance, employee retention and service quality [1].

Sasa Batistic et al (2016) emphasized the role of the organizational context by adopting a multilevel approach. It is found that combining a strong HR commitment configuration with a weak communal-sharing climate is associated with more employee proactivity [9].

Jalal Hanaysha (2016) aims to examine the effects of three factors namely employee empowerment, teamwork and employee training on organizational commitment in Malaysian higher education context. The findings confirmed that employee training has a significant positive effect on organizational commitment [2].

Qian Ling et al (2016) tests a trickle-down effect regarding how servant leadership flows from top-to middle-level leaders, resulting in frontline employees' service-oriented behaviors and service quality. Results support the service profit chain theory and trickledown model of leadership by demonstrating influence of top- and middle-level servant leadership on frontline employees [7].

Rajib Lochan Dhar (2015) examined the attitudes of employees working in Indian hotels catering to tourists. It analyzed their perception of training opportunities and the impact of such training on the service provided to guests. An integrated model was developed highlighting the relationship between perceived accessibility to training, perceived support for training, perceived benefits from training, and the implications of training on service quality mediated through organizational commitment. The findings of the study reveal a strong relationship between employee training and the quality of services offered by employees in tourist hotels [8].

Nima Jafari et al (2015) aims to explore how to enhance employee's satisfaction by means of e-learning systems, and what kinds of training or teaching activities are effective to increase their learning satisfaction. Findings from the study confirmed the validity of the proposed model for e-learning satisfaction assessment. In addition, the results showed that the four variables technology, educational content, motivation, and attitude significantly influenced employee's learning satisfaction [5]. 
Ahmet Bulent Ozturk et al (2014) focused primarily on the effect of job characteristics on job satisfaction and organizational commitment in the hotel industry. The results indicated that the job characteristics, interaction, feedback, and autonomy had significant impacts on both job satisfaction and affective commitment [6].

Martin et al (2013) analyzed the nature and characteristics of various training methods and the relationships among them using the following seven criteria: learning modality, learning environment, trainer presence, proximity, interaction level, cost considerations, and time demands. Results from this in-depth review suggest that the majority of training methods are not interactive, involve doing, and are off-the-job [4].

\subsection{Problem Statement}

It is evident from the literature reviewed that training is gaining its importance which benefited both the employees as well as organization. Some of the research work has been done on Training and Development in Hotel Industry but not any of study is related to Luxury Hotels of MP so far, therefore present study has been on this backdrop, "Training Effectiveness in Hotel Industry with Special reference to Luxury Hotels in MP”.

\subsection{Objectives of Research}

1. To assess the training needed in the Hotel Industry.

2. To understand the types of training provided in the Hotel Industry.

3. To examine the training programs that has been held in the light of viability and effectiveness.

4. To study managers and employees perception and opinion on the training program held on the effectiveness of training.

5. To analyze the training effectiveness on employees overall performance and productivity in Hotel Industry of Madhya Pradesh.

\subsection{Hypotheses}

* $\mathbf{H}_{10}$ : There is no significant difference amongst the opinion of Employees with different Work Experience regarding selected operational factors.

* $\mathbf{H}_{1 \mathrm{~A}}$ : There is a significant difference amongst the opinion of Employees with different Work Experience regarding selected operational factors.

* $\mathbf{H}_{\mathbf{2 0}}$ : There is no significant difference amongst the opinion of Employees with different Designations regarding selected operational factors.

* $\mathbf{H}_{2 \mathrm{~A}}$ : There is a significant difference amongst the opinion of Employees with different Designations regarding selected operational factors.

* $\mathbf{H}_{\mathbf{3 0}}$ : There is no significant difference amongst the opinion of Managers with different Designations regarding selected operational factors.

* $\mathbf{H}_{3 \mathrm{~A}}$ : There is a significant difference amongst the opinion of Employees with different Designations regarding selected operational factors.

\subsection{Tools for Hypotheses Testing}

* Reliability test:

* Normality test:

* Chi-Square test for Independence 


\section{Data Analysis}

\section{* Testing of Reliability (Employees)}

\begin{tabular}{|c|l|c|c|}
\hline $\begin{array}{c}\text { S. } \\
\text { No. }\end{array}$ & \multicolumn{1}{|c|}{ Factors } & $\begin{array}{c}\text { Cronbach's } \\
\text { Alpha }\end{array}$ & $\begin{array}{c}\text { Cronbach's Alpha } \\
\text { with missing item }\end{array}$ \\
\hline 1 & Necessity of Training & 0.892 & 0.882 \\
\hline 2 & Adequacy of Communication \& Teaching Skills & 0.892 & 0.892 \\
\hline 3 & Willingness of senior managers to help the juniors & 0.892 & 0.893 \\
\hline 4 & Quality of Work & 0.892 & 0.889 \\
\hline 5 & More Productive use of Resource & 0.892 & 0.885 \\
\hline 6 & Reducing Wastage \& Minimizes the Cost & 0.892 & 0.882 \\
\hline 7 & Minimizes the Need of Supervision & 0.892 & 0.881 \\
\hline 8 & Reducing Accidents & 0.892 & 0.886 \\
\hline 9 & Build Current Knowledge and Skills & 0.892 & 0.887 \\
\hline 10 & Job Role Enhancement & 0.892 & 0.893 \\
\hline 11 & Healthy Interpersonal Relationships & 0.892 & 0.884 \\
\hline 12 & Improves Performance and Productivity & 0.892 & 0.892 \\
\hline 13 & Salary & 0.892 & 0.881 \\
\hline 14 & Job Satisfaction & 0.892 & 0.880 \\
\hline 15 & Proper Performance Evaluation & 0.892 & 0.882 \\
\hline 16 & Promotion & 0.892 & 0.884 \\
\hline 17 & Career Advancement Opportunity & 0.886 \\
\hline 18 & Rating of Training Programme & 0.891 \\
\hline 1 & & 0.892 & 0 \\
\hline
\end{tabular}

It is clearly evident that Cronbach's Alpha is 0.892, which indicates a high level of internal consistency for our scale with this specific sample. It is interpreted that the data collected from these Luxury Hotels has been reliable.

\section{* Normality Statistics (Employees)}

\begin{tabular}{|c|c|c|c|c|}
\hline \multirow{2}{*}{$\begin{array}{l}\text { S. } \\
\text { No. }\end{array}$} & \multirow{2}{*}{ Factors } & \multicolumn{3}{|c|}{ Shapiro-Wilk } \\
\hline & & Statistic & Df & Sig. \\
\hline 1 & Necessity of Training & 0.748 & 119 & 0.000 \\
\hline 2 & Adequasy of Cotrumunisation \& Teaching Skills. & 0.774 & 119 & 0.000 \\
\hline 3 & Willingness of senior managers to help the juniors & 0.810 & 119 & 0.000 \\
\hline 4 & Quality of Work & 0.747 & 119 & 0.000 \\
\hline 5 & More Productive use of Resourve & 0.759 & 119 & 0.000 \\
\hline 6 & Redracing Wastage \& Minimizes the Cost & 0.727 & 119 & 0.000 \\
\hline 7 & Minimizes the Nesd of Supervision & 0.740 & 119 & 0,000 \\
\hline 8 & Reduwing Aceidents & 0.741 & 119 & 0.000 \\
\hline 9 & Build Current Knowsledge and Skills & 0.755 & 119 & 0.000 \\
\hline 10 & Job Role Enhancement & 0.778 & 119 & 0.000 \\
\hline 11 & Healthy Interpersonal Relationahipe & 0.745 & 119 & 0.000 \\
\hline 12 & Improves Performance and Productivity & 0.764 & 119 & 0.000 \\
\hline 13 & Saliary & 0.777 & 119 & 0.000 \\
\hline 14 & Job Satisfaction & 0.721 & 119 & 0.000 \\
\hline 15 & Proper Performanee Evaluation & 0.738 & 119 & 0.000 \\
\hline 16 & Promotion & 0.758 & 119 & 0.000 \\
\hline 17 & Career Advancenent Opporthaity & 0.742 & 119 & 0.000 \\
\hline 18 & Rating of Training Programune & 0.831 & 119 & 0.000 \\
\hline
\end{tabular}


From the above table it has been concluded that the significance value of the Shapiro-Wilk is less than 0.05 , so the data is significantly deviate from a normal distribution.

\section{* Descriptive Statistics (Employees)}

\begin{tabular}{|c|c|c|c|c|c|c|}
\hline $\begin{array}{c}5 . \\
\text { Y. }\end{array}$ & Factors & Meas & $\begin{array}{l}\text { Stadarad } \\
\text { Frrner }\end{array}$ & $\begin{array}{l}\text { Standard } \\
\text { Deviatian }\end{array}$ & $\begin{array}{l}\text { Salaph } \\
\text { Variasere }\end{array}$ & Weieht \\
\hline 1 & Necessity of Training & 4.20 & 0.0735 & 0.505 & 0.649 & 0.840 \\
\hline 2 & $\begin{array}{l}\text { Adequacy of Commumication \& } \\
\text { Teaching Skills }\end{array}$ & 4.27 & 0.0765 & 0.837 & 0.701 & 0.853 \\
\hline 3. & $\begin{array}{l}\text { Willinguess of senior managers to } \\
\text { belp the juniors }\end{array}$ & 3.99 & 0.0913 & 1.000 & 1.000 & 0.798 \\
\hline 4 & Qualify of Wouk & 4.19 & 0.0732 & 0.802 & 0.644 & 0.838 \\
\hline 5 & More Productive use of Resourse & 4.18 & 0.0697 & 0.763 & 0.583 & 0.835 \\
\hline 6 & $\begin{array}{l}\text { Reducing Wastage \& Minianizes } \\
\text { the Cost }\end{array}$ & 4.33 & 0.0838 & 0.918 & 0.843 & 0.565 \\
\hline 7 & $\begin{array}{l}\text { Minimizes the Need of } \\
\text { Supervision }\end{array}$ & 4.27 & 0.0826 & 0.905 & 0.819 & 0.853 \\
\hline 8 & Reducing Aecident" & 4.23 & 0.0826 & 0.905 & 0.819 & 0.847 \\
\hline 9 & $\begin{array}{l}\text { Build Courent Knowledge and } \\
\text { Skills }\end{array}$ & 4.26 & 0.0824 & 0.903 & 0.815 & 0.552 \\
\hline 10 & Job Role Enhancernent & 4.17 & 0,0761 & 0.833 & 0.695 & 0.833 \\
\hline 11 & $\begin{array}{l}\text { Healthy Interpersonal } \\
\text { Relationships }\end{array}$ & 4.13 & 0.0825 & 0.903 & 0.816 & 0.525 \\
\hline 12 & $\begin{array}{l}\text { Improves Performance and } \\
\text { Productivity }\end{array}$ & 4.17 & 0.0806 & 0.882 & 0.779 & 0.833 \\
\hline 13 & Salary & 3.91 & 0.1025 & 1.123 & 1.260 & 0.782 \\
\hline 14 & Job Satisfaction & 4.31 & 0,0852 & 0.933 & 0.871 & 0.862 \\
\hline 15 & Proper Performance Evaluation & 3.98 & 0.0924 & 1.012 & 1.025 & 0.797 \\
\hline 16 & Promotion & 4.23 & 0.0835 & 0.914 & 0.836 & 0,847 \\
\hline 17 & Career Advancement Opportunity & 4.16 & 0.0853 & 0.935 & 0.874 & 0.832 \\
\hline 18 & Rating of Training Programme & 3.93 & 0.0884 & 0.968 & 0.937 & 0.787 \\
\hline
\end{tabular}

The descriptive statistics shown in the above table depicts the ranking of training effectiveness on selected parameters. Top five parameters highlighted in the table on which training has major impact are: Reducing Wastage \& Minimizes the Cost, Job Satisfaction, Adequacy of Communication \& Teaching Skills, Minimizes the Need of Supervision \& Build Current Knowledge and Skills.

\section{* Testing of hypothesis (Employees)}

$\mathbf{H}_{10}$ : There is no significant difference amongst the opinion of Employees with different Work Experience regarding selected operational factors.

$\mathbf{H}_{\mathbf{1 A}}$ : There is a significant difference amongst the opinion of Employees with different Work Experience regarding selected operational factors.

The null hypothesis is accepted, since for all 18 operational factors the $\mathrm{p}$ value $<0.05$, that fulfills $95 \%$ confidence level of responses. It shows that there is no significant difference amongst the opinion of Employees with different work experience regarding the selected operational factors. Therefore impact of training on all above mentioned factors is same with respect to the employees having different work experience.

$\mathbf{H}_{\mathbf{2 0}}$ : There is no significant difference amongst the opinion of Employees with different Designations regarding selected operational factors.

$\mathbf{H}_{\mathbf{2}}$ : There is a significant difference amongst the opinion of Employees with different Designations regarding selected operational factors. 


\begin{tabular}{|c|c|c|c|c|}
\hline S. No. & Factors & chlt-19 & p-value & isg \\
\hline 1 & Necessity of Inining & 34.1556 & 0.0251 & you \\
\hline 2 & Adequacy of Communication \& Teaching Stills & 33.6409 & 0.0287 & yo \\
\hline 3 & Willingness of senior managers to help the junions & 36.1606 & 0.0147 & yo \\
\hline 4 & Quality of Work & 39.5004 & 0.0058 & you \\
\hline 5 & More Productive use of Resoure & 36.6933 & 0.0127 & $y=$ \\
\hline 6 & Reducing Wastage \& Minimizes the Cost & 32.4022 & 0.0392 & yea \\
\hline 7 & Minimizs the Nead of Supervision & 37.0153 & 0.0117 & $y \mathbf{a}$ \\
\hline 8 & Reducing Ascidents & 35.6515 & 0.0169 & ya \\
\hline 9 & Build Current Knowledge and Skills & 33.924 & 0.0266 & you \\
\hline 10 & Job Role Enhancensent & 34.2496 & 0.0083 & ye \\
\hline 11 & Healthy listerpersonal Relationships & 39.7634 & 0.0044 & yes \\
\hline 12 & Improves Performasce and Prodnctivity & 41.2517 & 0.0035 & $y=$ \\
\hline 13 & Salary & 33.065 & 00082 & ye \\
\hline 14 & Job Sstisfaction & 40.5948 & 0.0042 & ya \\
\hline 15 & Proper Performance Evaluation & 33.1204 & 0.0327 & yo \\
\hline 16 & Promotion & 42.6542 & 0.0023 & ye \\
\hline 17 & Career Advancemetit Opportunity & 329955 & 0.0338 & yo \\
\hline 18 & Rating of Training Progranume & 40.5051 & 0,0013 & $y=$ \\
\hline
\end{tabular}

\begin{tabular}{|c|c|c|c|c|}
\hline S. No. & Factors & chi-se & p-ralue & $\operatorname{sig}$ \\
\hline 1 & Necessity of Training & 245160 & 0.0173 & yes \\
\hline 2 & Adequacy of Communication \& Teaching Skills & 21.7413 & 0.0405 & yes \\
\hline 3 & Willingness of senior managers to help the juniors & 22.5785 & 0.0315 & yes \\
\hline 4 & Quality of Work & 28.8096 & 0.0042 & yes \\
\hline 5 & More Productive use of Resource & 27.6779 & 0.0062 & yes \\
\hline 6 & Reducing Wastage \& Minimizes the Cost & 259123 & 0.0110 & yes \\
\hline 7 & Minimizes the Need of Supervision & 22.4906 & 0.0324 & yes \\
\hline 8 & Reducing Accidents & 28.4387 & 0.0048 & yes \\
\hline 9 & Boild Current Knourledge and Skills & 23.6848 & 0.0224 & yes \\
\hline 10 & Job Role Enhancement & 245961 & 0.0169 & yes \\
\hline 11 & Healthy Interpersconal Relationships & 24.7893 & 0.0159 & yes \\
\hline 12 & Improves Performance and Productivity & 22.0763 & 0.0367 & yes \\
\hline 13 & Salary & 22.5606 & 0.0317 & yes: \\
\hline 14 & Job Safisfaction & 27.7300 & 0.0060 & yes \\
\hline 15 & Proper Performance Evaluation & 28.7588 & 0.0043 & yes \\
\hline 16 & Promotion & 23.7282 & 0.0221 & yes \\
\hline 17 & Career Advancement Opportunity & 28.2782 & 0.0050 & yes \\
\hline 18 & Rating of Training Programme & 23.4106 & 0.0244 & yes \\
\hline
\end{tabular}

The null hypothesis is accepted, since for all 18 operational factors the $p$ value $<0.05$, that fulfills $95 \%$ confidence level of responses. It shows that there is no significant difference amongst the opinion of Employees working in different designations and departments regarding the selected operational factors. Therefore impact of training on all above mentioned factors is same with respect to the employees working in different designations and departments. 


\section{* Testing of Reliability (Managers)}

\begin{tabular}{|c|c|c|c|}
\hline $\begin{array}{l}\text { S. } \\
\text { Ne. }\end{array}$ & Factors & $\begin{array}{c}\text { Cronbach's } \\
\text { Alpha }\end{array}$ & $\begin{array}{l}\text { Cronbach's Alpha } \\
\text { with missing item }\end{array}$ \\
\hline 1 & Job Knowledpe and Skills & 0.722 & 0.706 \\
\hline 2 & Sound Relationship & 0.722 & 0.719 \\
\hline 3 & Higher Level Task & 0.722 & 0.699 \\
\hline 4 & Effective performance & 0.722 & 0.690 \\
\hline 5 & Quantity and Quality & 0.722 & 0.683 \\
\hline 6 & Reduces Sapenvision, Wastages and Accidents & 0.722 & 0.665 \\
\hline 7 & Reduces Labour Tumover and Absenteciam & 0.722 & 0.672 \\
\hline 8 & Prounotica & 0.722 & 0.664 \\
\hline 9 & Motivation & 0.722 & 0,721 \\
\hline 10 & Pay and Promotions & 0.722 & 0.742 \\
\hline 11 & On the Job Training & 0.722 & 0.749 \\
\hline 12 & Evaluatica & 0.722 & 0,694 \\
\hline 13 & Career Opportunities & 0,722 & 0.744 \\
\hline
\end{tabular}

It is concluded that Cronbach's Alpha is 0.722 , which indicates a high level of internal consistency for our scale with this specific sample. The data collected from the managers of selected Luxury Hotels is reliable.

\section{* Normality Statistics (Managers)}

\begin{tabular}{|c|c|c|c|c|}
\hline S. & \multirow{2}{*}{ Factors } & \multicolumn{3}{|c|}{ Shapiro-Wilk } \\
\hline $\mathrm{No}_{0}$ & & Statistic & Df & Sig. \\
\hline 1 & Job Knomlodge and Shlls & 0.773 & 29 & 0.000 \\
\hline 2 & Sound Relationslip & 0.732 & 29 & 0.000 \\
\hline 3 & Higher Level Task & 0.825 & 29 & 0.000 \\
\hline 4 & Effective pefformance & 0.804 & 29 & 0.000 \\
\hline 5 & Quantity and Quality & 0.802 & 29 & 0.000 \\
\hline 6 & Retuses Supervision. Wastages and Accidents & 0.708 & 29 & 0.000 \\
\hline 7 & Rotuces Labour Tumover and Absenteciom & 0.695 & 29 & 0.000 \\
\hline 8 & Promotion & 0.757 & 29 & 0.000 \\
\hline 9 & Motriation & 0.826 & 29 & 0.000 \\
\hline 10 & Pay and Promotions & 2.689 & 29 & 0.000 \\
\hline 11 & On the Job Iraining & 0.795 & 29 & 0.000 \\
\hline 12 & Eraluation & 0.682 & 29 & 0.000 \\
\hline 13 & Carear Oppontaities & 0.779 & 29 & 0.000 \\
\hline
\end{tabular}

From the above table it has been concluded that the significance value of the Shapiro-Wilk is less than 0.05 , so the data is significantly deviate from a normal distribution.

\section{* Descriptive Statistics (Managers)}

\begin{tabular}{|c|c|c|c|c|c|c|}
\hline s. & Factors & Mers & $\begin{array}{l}\text { Maudarid } \\
\text { Errof }\end{array}$ & $\begin{array}{l}\text { neasdard } \\
\text { Deriatien }\end{array}$ & $\begin{array}{c}\text { Salaple } \\
\text { Vurianer }\end{array}$ & Weicht \\
\hline 1 & Jeb Knowledge and Stalls & 4.10 & 0.211 & L.159 & 1.34 & 0.820 \\
\hline 2 & Sound Relationehip & 4.13 & 0.208 & 1.139 & 1.292 & 0.827 \\
\hline 3 & Higher Level Tauk & 3.90 & 0.182 & 0.995 & 0.990 & 0.780 \\
\hline 4 & Etfective perfornaance & 3,87 & 0.208 & 1.137 & 1.292 & 0.773 \\
\hline 5 & Quantity and Quality & 3.97 & 0.160 & 0.928 & 0.161 & 0.793 \\
\hline 6 & $\begin{array}{l}\text { Reduces Supervision. Wastager } \\
\text { and Accidenh }\end{array}$ & $4: 27$ & 0.191 & 1.048 & 1.099 & 0.853 \\
\hline 7 & $\begin{array}{l}\text { Rechices Labour Turnoter and } \\
\text { Abseatesian }\end{array}$ & 4.20 & 0.206 & 1.126 & 1.269 & 0.540 \\
\hline$\|$ & Mombatios & 4.13 & 0.208 & 1.137 & 1.292 & 0.527 \\
\hline 9 & Motivation & 397 & 0.176 & 0.964 & 0.930 & 0.793 \\
\hline 10 & Pay and Promotions & 4.20 & 0.222 & 1.219 & 1.476 & 0.840 \\
\hline 11 & On the Job Training & 3.90 & 0.158 & 1.029 & 1.059 & 0.780 \\
\hline 12 & Evaluation & 4.23 & 0.207 & 1.135 & 1.289 & 0.847 \\
\hline 13 & Career Opportunitien & 4.03 & 0.182 & 0.999 & 0.999 & 0.807 \\
\hline
\end{tabular}


The descriptive statistics shown in the above table depicts the ranking of training effectiveness on selected parameters. Top five parameters highlighted in the table on which training has major impact are: Reduces Supervision, Wastages and Accidents, Evaluation, Pay and Promotions, Promotion \& Sound Relationship.

\section{* Testing of hypothesis}

$\mathbf{H}_{30}$ : There is no significant difference amongst the opinion of Managers with different Designations regarding selected operational factors.

$\mathbf{H}_{3 \mathbf{A}}$ : There is a significant difference amongst the opinion of Employees with different Designations regarding selected operational factors.

\begin{tabular}{|c|c|c|c|c|}
\hline S. No. & Factors & chit-sq & $p$-value & sig \\
\hline 1 & Job Knowledge and Stills & 21.192 & 0.048 & yes \\
\hline 2 & Sound Relationship & 22.828 & 0.029 & yes \\
\hline 3 & Higher Level Task & 22.526 & 0.032 & yes \\
\hline 4 & Effective perfomanuse & 23.249 & 0.026 & yes \\
\hline 5 & Quantity and Quality & 27.091 & 0.007 & yes \\
\hline 6 & Redoses Supernision, Wastages and Accideuts & 23.340 & 0.025 & yes \\
\hline 7 & Reduces Labour Tumover and Absentecism & $25: 298$ & 0.013 & yes \\
\hline 8 & Promotion & 28.410 & 0.005 & yes \\
\hline 9 & Motivation & 23.901 & 0.021 & yes \\
\hline 10 & Pay and Promotions & 23.035 & 0.027 & yes \\
\hline II & Oa the Job Inining & 25.120 & 0.014 & yes \\
\hline 12 & Evaluation & 27.144 & 0.007 & yes \\
\hline 13 & Career Oppontunities & 25.010 & 0.015 & yes \\
\hline
\end{tabular}

The null hypothesis is accepted, since for all 13 operational factors the $p$ value $<0.05$, that fulfills $95 \%$ confidence level of responses. It shows that there is no significant difference amongst the opinion of Managers with different Designations regarding the selected operational factors. Therefore impact of training on all above mentioned factors is same with respect to the managers having different Designations.

\section{Findings}

* Training is given priority and is of strategic advantage for Hotels as said by managers in all the units.

* It was found that all departments are actively involved in regular training sessions headed by training managers.

* Training is regarded as an important HR tool by both employees as well as managers. Employees are self-motivated to attend such training programs as it results into their skill enhancement \& improving their interpersonal skill.

* Need based Training Sessions are arranged on the regular basis as it is an on-going process.

* Training sessions help employees to build sound and healthy relationships with the job and the colleagues as well as with the superiors.

* Training is positively associated with the Quantity and Quality of Work.

* The training helps the employees of Hotel Industry to work efficiently without much supervision, to make the more productive use of resources which results in minimum wastages of resources, and to deal with the critical situation. 
Evaluation of employee's performance has been done properly by the top management authorities to let them know about their strength and weakness on the basis of comparing desired performance with actual performance.

* It has been found that the trainers who impart the basic job knowledge possess excellent communication skills as well as teaching skills.

\section{Scope for Further Research}

* The present research focuses only on Luxury segment of Hotel Industry. Further research can be enlarging to other mid- segment and budget segment hotels also.

* A comparative study on Heritage Hotels and resorts can also be done.

* This research study consists of only selected Luxury Hotels of major cities of MP. Further research can include other state Luxury Hotels to know about their training procedures.

\section{References:}

I. Islam El-Bayoumi Salem, Mohamed Kamal Abdien (2017) "Implementation of employee cross-training during perilous conditions in hotels", Tourism Management Perspectives, Vol. 23, p.p. 68-74.

II. Jalal Hanaysha, (2016), "Examining the Effects of Employee Empowerment, Teamwork, and Employee Training on Organizational Commitment", International Conference on Leadership, Technology, Innovation and Business Management, Vol. 229, p.p. 298 - 306.

III. Lillian T. Eby, Tammy D. Allen, Kate M. Conley, Rachel L. Williamson, Tyler G. Henderson, Victor S. Mancini (2017) "Mindfulness-based training interventions for employees: A qualitative review of the literature", Human Resource Management Review.

IV. Martin, B.O., Kolomitro, K., Lam, T.C., (2014). Training methods a review and analysis. Hum. Resour. Dev. Rev. 13 (1), 11-35.

V. Nima Jafari Navimipour, Batool Zareie, (2015), "A model for assessing the impact of elearning systems on employees' satisfaction", Computers in Human Behavior, Vol. 53, p.p. $475-485$.

VI. Ozturk, A.B., Hancer, M., Im, J.Y., (2014). Job characteristics, job satisfaction, and organizational commitment for hotel workers in Turkey. J. Int. J. Hosp. Manage. 23 (3), 294-313.

VII. Qian Ling, Meizhen Lin, Xiaoyi Wu, (2016), "The trickle-down effect of servant leadership on frontline employee service behaviors and performance: A multilevel study of Chinese hotels", Tourism Management, Vol. 52, p.p. 341-368.

VIII. Rajib Lochan Dhar, (2015) "Service quality and the training of employees: The mediating role of organizational commitment", Tourism Management, Vol. 46, p.p. 419430.

IX. Sasa Batistic, Matej Cerne, Robert Kase, Ivan Zupic, (2016), "The role of organizational context in fostering employee proactive behavior: The interplay between HR system configurations and relational climates", European Management Journal, p.p. 1-10.

X. Wen Chang, James A. Busserb (2017) "Hospitality employees promotional attitude: Findings from graduates of a twelve-month management training program", International Journal of Hospitality Management, Vol. 60, p.p. 48-57. 